\title{
Gulf of Mexico Seafood Harvesters: Part 3. Potential Occupational Risk Reduction Measures
}

\author{
Melvin L. Myers 1,2,*, Robert M. Durborow ${ }^{2,3}$ and Andrew S. Kane ${ }^{2,4}$ \\ 1 Rollins School of Public Health, Emory University, Atlanta, GA 30322, USA \\ 2 Southeastern Coastal Center for Agricultural Health and Safety, University of Florida, Gainesville, FL 32611, \\ USA; robert.durborow@kysu.edu (R.M.D.); kane@ufl.edu (A.S.K.) \\ 3 Land Grant Program and State Extension Specialist for Aquaculture, Kentucky State University, Frankfort, \\ KY 40601, USA \\ 4 Department of Environmental and Global Health, College of Public Health and Health Professions, \\ University of Florida, Gainesville, FL 32611, USA \\ * Correspondence: melvinmyers@charter.net; Tel.: +1-404-310-5061
}

Received: 1 May 2018; Accepted: 23 July 2018; Published: 2 August 2018

\begin{abstract}
Background: Fishers face many occupational hazards that include a high risk of fatal and nonfatal injuries and a variety of adverse health effects. Our purpose is to provide an overview of potential countermeasures for the control of hazards that threaten the health and safety of Gulf of Mexico (GoM) fish harvesters. 2. Method: Search terms were used to identify relevant literature; two previous reviews regarding injuries and health risk factors also inform this review. 3. Results: Countermeasures against these hazards include winch guards, lifting devices, job redesign, non-slip decks and vessel stability controls as well as using personal flotation devices, wearing gloves and high-friction footwear, increasing sleep time and using vessel motion to assist lifting. Knowledge about secondary prevention (such as rescue, first aid and making mayday calls) is also important. Learning through experience is a crucial factor that incorporates other fishers' experiences with innovations. Fatigue and lack of sleep contribute to vessel disasters and injury-related errors. 4. Conclusions: The prevention of injuries and diseases among GoM fishers depends on a combination of focusing on work-processes, instilling a broader safety culture, engineering controls, identifying and sharing fisher innovations, promoting fall overboard prevention and protection and providing culture-based incentives, training and narrative outreach.
\end{abstract}

Keywords: countermeasures; fishing; aquaculture; prevention; safety; engineering controls; training; personal protective device; ergonomics; safety

\section{Introduction}

This review is the third in a series of descriptive literature reviews and it addresses the prevention of a range of potential injuries and adverse health effects among US Gulf of Mexico (GoM) fish harvesters. The first review described injury risk factors among fish harvesters that included falls overboard (FOB), slippery and inherently unstable work platforms, working alone, not wearing personal flotation devices (PFDs), vessel casualties, lack of response time to crises, lack of vessel repair and maintenance, harsh weather, gear and line contact including winch entanglements, fatigue, lack of a safety culture and onshore hazards, including boarding and debarking the vessel. It also addressed fatigue as a risk factor for human error regarding vessel disasters and injuries [1]. In our second review, we identified risk factors for adverse health effects other than traumatic injuries, which included musculoskeletal disorders, poisoning from aquatic animals, dermatitis, cancer, ocular disorders, hearing loss and respiratory problems as well as diving hazards [2]. For a geographical 
perspective of the GoM, Figure 1 shows a map of the GoM and locations of fish harvester fatalities over the period 2010-2014, which represents the most severe malady facing these workers. A vessel disaster is defined a sinking, capsizing, grounding, fire, or other event that forces the crew to abandon ship [3].

The purpose of this review is to identify and describe potential countermeasures for the control of hazards that threaten the occupational health and safety of US Gulf of Mexico (GoM) fish harvesters based on an overview of the literature. Literature from outside the GoM informs countermeasures that are potential interventions for protection of fish harvesters in the Gulf. The audience of this analysis is researchers and interveners for the safety of fish harvesters.

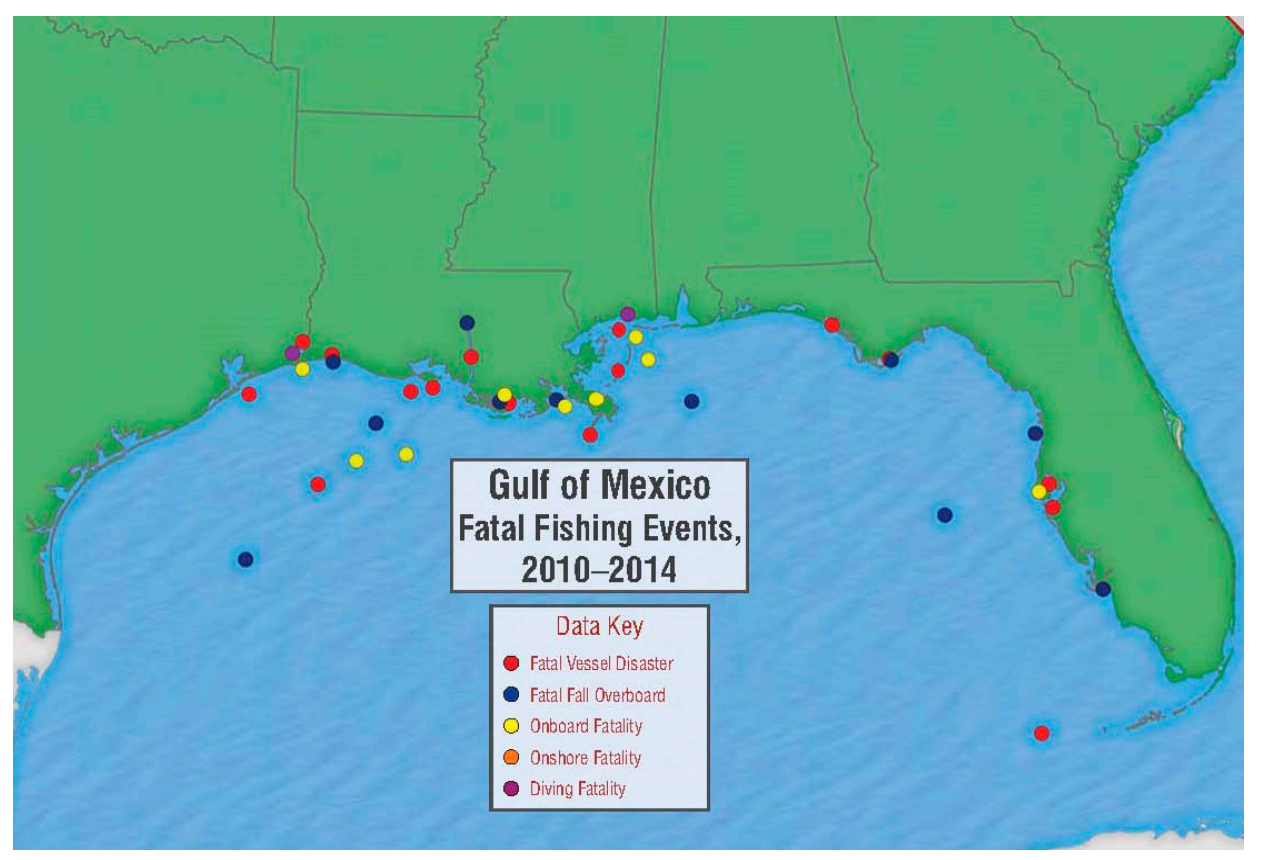

Figure 1. A map depicting the US Gulf of Mexico waters and the types of fatalities of fish harvesters there. Source: Syron et al., 2017 [3], Courtesy National Institute for Occupational Safety and Health (NIOSH), open access.

\section{Method and Materials}

This normative literature review identifies studies that inform our broader study, Occupational Health and Safety of Gulf Seafood Workers Project, based on three health priorities: (1) severity of the individual case (e.g., fatality); (2) frequency of the condition (e.g., back pain that is frequently reported) and (3) preventability, (e.g., PFD use to prevent drowning). We consulted several databases including google scholar and PubMed as well as the authors' files. Search terms reflected occupational safety and health in the fishery sector that included in combination (string search); safety, injuries, health, fishing, aquaculture, engineering, drowning, Gulf of Mexico and several specific terms such as ocular hazards and solar radiation. We also consulted a NIOSH bibliography $(n=156)[4]$ and Proceedings of the International Fishing Industry Safety and Health Conferences of 2000 and 2003 ( $n=43$ and 40, respectively) [5,6], Recent articles were also identified and provided by contacts through ResearchGate. Selection criteria were (1) direct or indirect relevance to GoM fisher safety and health; (2) recent investigations that build on earlier investigations and (3) research designs that can inform our study. Exclusion criteria were studies that did not address interventions regarding occupational safety and health of fish harvesters. Typically, we chose literature that was published since 2002 with few exceptions. We selected 52 articles for review as listed in the Appendix A. 


\section{Results}

Our results start with studies from within the GoM followed by safety culture and how it fits into the fishing culture. Next, work processes are explained as a way to understand where the risks occur in order to eliminate or abate hazards. Then the following topics are discussed: potential engineering controls for preventing falls overboard (FOB), machine and line entanglements, vessel instability, musculoskeletal hazards, falls on vessels and injuries and illnesses in mariculture. Following engineering controls, personal protective equipment, how incentives have been used, the need for training and the importance of using stories through narrative outreach are addressed.

\subsection{Gulf of Mexico Interventions}

"Culture refers to a way of life of a group of people: the patterns of behavior among this group, their beliefs, values and symbols they accept, generally without thinking of them."

$$
\text { —Ann K. Carruth et al., } 2010 \text { [7] }
$$

Fisher safety and health research in the Texas and Louisiana areas of the GoM was started by Levin et al. in 2004, an area where many Vietnamese shrimpers work. The study trained 535 fishers how to signal their presence to approaching vessels by horn and how to radio mayday calls in English and used the Vietnamese language to overcome a barrier in communicating safety messages to immigrant fishers. In addition to overcoming the language barrier, hands-on training used a simulated vessel bridge and targeted captains for the training [8].

In 2005, a 30-question survey was administered to 133 fishers along the Texas coast, 59\% of whom primarily fished for shrimp. Subjects included Asians $(n=76 ; 57 \%)$ and Hispanics $(n=35$; $26 \%$ ). Familiarity with safety equipment varied from a high of $91 \%$ of respondents knowing how to don a personal floatation device (PFD) to $62 \%$ of respondents knowing how to activate an electronic emergency beacon, 50\% knowing how to deploy a survival craft, $47 \%$ having an awareness of machine hazards and $44 \%$ knowing chemical and preservative hazards. Of the respondents, $81 \%$ believed alcohol consumption at sea can cause accidents. Fifty-nine percent of respondents believed that the work was very safe to neutral. However, $70 \%$ of the shrimpers held this belief despite a high fatality rate. Shrimpers (59\%) had a higher participation rate than non-shrimpers $(18 \%)$ in annual training. They received language-appropriate training and instruction focused on risk factor awareness especially about the use of survival crafts and machine-related hazards [9].

A focus group-based study of safety culture among Vietnamese GoM fishers was conducted that included adult family members of the fishers, specifically women, who treat illnesses and injuries of family members and uniquely express cultural memories of ethnic groups. Key results about the safety culture on vessels included (1) essential leadership skills of the captain; (2) deck hands learning through on-the-job training and (3) the inclusion of family members as stakeholders [7].

Based on focus group feedback, interventions were launched in the GoM in 2008 to address fatigue, machinery/winch and hearing hazards. Asian fishers predominated in the pretest survey $(n=217)$ in 2008 and post-test survey $(n=206)$ in 2012. Interventions included training and safety messaging with signs and written information. For hearing protection, signs were attached to engine room doors with protective ear muffs placed on door hangers as shown in Figure 2. Signs regarding machinery were placed near the vessel winches and a checklist was posted on signs reminding the fishers to rest to counter fatigue. The intent for action or adoption in three groups was high at $82 \%$, $95 \%$ and $95 \%$, respectively [10]. 


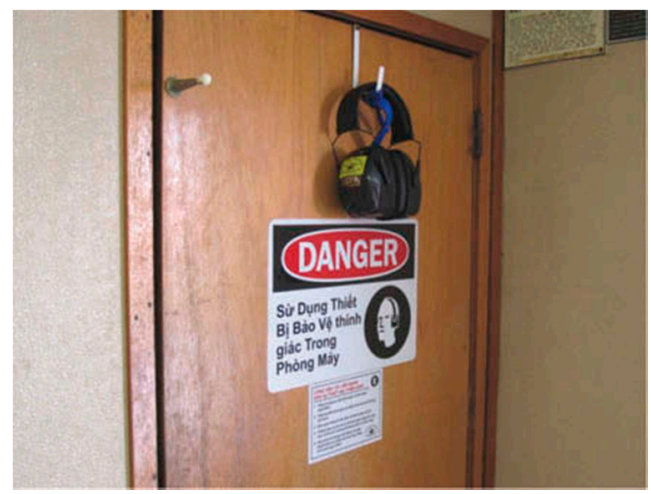

Figure 2. Signage and ear muffs on engine room door. Courtesy of Jeffrey L. Levin, M.D., University of Texas with approval by the Journal of Agromedicine [8].

Winch entrapment was identified as a major hazard aboard shrimping vessels in the GoM [11]. Countermeasures to this hazard for the GoM were informed by a previous study in Alaska in which winch entanglements on purse-seine vessels related to the deployment and retrieval of fishing gear. The off-switch was out of reach of an entangled fisher; thus, the research engineers designed an emergency stop button on top of the electrohydraulic-powered winch to stop the power instantaneously. Rather than using hydraulic power, many winches used on fishing vessels in the GoM are powered mechanically by a power take-off system connected directly to the vessel engine [12]. Thus, research engineers designed and fabricated guards, and three vessel owners in the GoM agreed to test them. One design is shown in Figure 3 [13]. The designs underwent their third test to improve endurance and acceptance in 2017 [14].

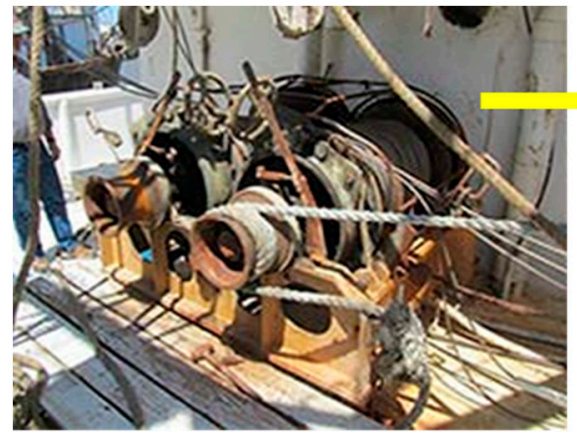

Before

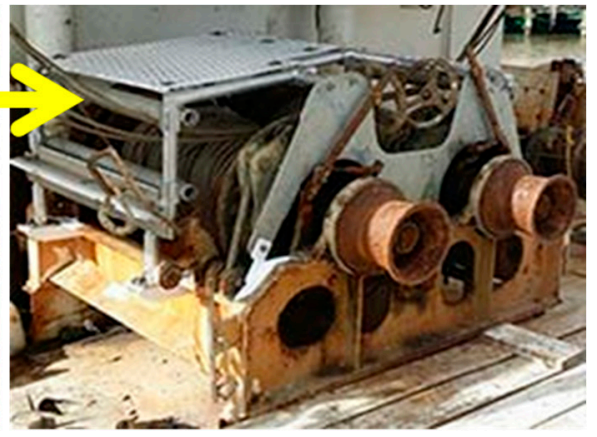

After

Figure 3. An example of a winch in a Gulf of Mexico vessel before and after a guard is attached. Source: NIOSH 2015 [12].

In another study, $300 \mathrm{GoM}$ fishers were trained on ergonomics for deck work where there is limited physical space, unstable work platforms and a wide variety of tasks and vessel layouts. The fishers $(98 \%)$ reported the highest value of the training was learning stretching exercises and $35 \%$ reported a high value for learning about lifting guidelines and body mechanics. The subjects suggested that the motion of the vessel could be used to assist in lifting or lowering loads $[15,16]$.

An additional study addressed PFD acceptance with 9 captains and 24 deckhands on Texas and Louisiana vessels. Each subject was asked to wear three different PFDs for a minimum of three hours while shrimping. Afterwards, the respondents reported the suspender as the least constrictive to movement as compared to the inflatable belt and ski belt [17]. More detail regarding PFDs will be addressed under Section 3.5. 


\subsection{Safety Culture}

"... safety can be defined as that state for which the risks are judged to be acceptable."

—Fred A. Manuele and Bruce W. Main, 2002 [18]

A gap analysis of fisher health concluded that cultural issues of total health and how the working conditions affect personal behavior risk, such as smoking and alcohol consumption (e.g., risk coping). More broadly, safety culture as part of fishing culture depends on acceptable risk by the fishers and more specifically, depends on the vessel captains [19]. Table 1 lists several studies and findings related to safety and fishing culture.

Table 1. A list of studies and findings related to the safety culture in the fishing culture, $n=9$.

\begin{tabular}{|c|c|}
\hline Study & Findings \\
\hline $\begin{array}{l}\text { Acheson interviewed } 12 \text { British Columbian fishers in } \\
\text { Canada from a variety of vessels types who had } \\
\text { experience with an injury or participated in } \\
\text { an incident [20]. }\end{array}$ & $\begin{array}{l}\text { Fishers downgrade risk by not reporting work injuries. Denial and } \\
\text { trivialization of danger is part of the occupational culture. The author } \\
\text { suggests fisher participation in which they discuss their own experience } \\
\text { through the lens of risk assessment and their own injuries and near misses. }\end{array}$ \\
\hline $\begin{array}{l}\text { Törner and Eklöf investigated fishers' attitudes } \\
\text { towards risks and attempted to enhance a sense of } \\
\text { risk control in their work. They began with a } \\
\text { questionnaire to } 92 \text { subjects followed by two } \\
\text { discussion groups of two and three crews that met six } \\
\text { times over eight months [21]. }\end{array}$ & $\begin{array}{l}\text { The fishers described } 43 \text { incidents and reported that technology was at fault } \\
\text { in } 34(79 \%) \text { of the incidents, deficient work organization was at fault in } 5 \\
(12 \%) \text { cases and } 4(9 \%) \text { were caused by an individual's actions. Common } \\
\text { factors included weather }(n=16 ; 37 \%) \text {, deficient routines }(n=10 ; 23 \%) \text { and } \\
\text { faulty equipment }(n=8 ; 19 \%) \text {. One conclusion was that slipping was a risk } \\
\text { factor, which was underreported since it became a norm. }\end{array}$ \\
\hline $\begin{array}{l}\text { Marshall et al. focused on } 215 \text { commercial fishers in } \\
\text { small and medium scale operations in North Carolina. } \\
\text { Most fishers were self-employed or working in small } \\
\text { operations [22]. }\end{array}$ & $\begin{array}{l}\text { A principle concern was making a "day-to-day living" and a general theme } \\
\text { included a reluctance to seek medical care and concerns regarding } \\
\text { regulations. They likely lacked job-related health insurance or workers' } \\
\text { compensation coverage. }\end{array}$ \\
\hline $\begin{array}{l}\text { Bezerra et al. conducted a study of } 19 \text { Brazilian } \\
\text { fishers that included an evaluation of clinical, } \\
\text { histological and immunological effects of chronic } \\
\text { exposure to ultraviolet radiation from the sun [23]. }\end{array}$ & $\begin{array}{l}\text { Fishers stay with their occupation longer than other workers and they start } \\
\text { as adolescents based on family tradition or contacts with other fishers. They } \\
\text { concluded that fishers learn through experience whereas workers in other } \\
\text { occupations require prior training and thus start work later in life. }\end{array}$ \\
\hline $\begin{array}{l}\text { Bye and Lamvick surveyed } 487 \text { employees and } \\
\text { interviewed } 45 \text { subjects from fishing and other } \\
\text { vessels in Norway to determine the relationship of } \\
\text { risk perception to countermeasures [24]. }\end{array}$ & $\begin{array}{l}\text { Small fishing vessels, } 35 \text { feet or less in length, were found as the most } \\
\text { dangerous but } 71 \% \text { of injuries were never reported. Several subjects stated } \\
\text { that their work was dangerous but they rarely discussed this danger among } \\
\text { crew members. Defects on the vessel could be easily fixed but remained } \\
\text { unrepaired. Fatalism ruled: } 13 \% \text { did not know how to swim, } 41 \% \text { said they } \\
\text { rarely donned a PFD and } 34 \% \text { rarely used a safety line on board. Donning a } \\
\text { PFD could lead to ridicule by the crew and fishers on passing vessels. }\end{array}$ \\
\hline $\begin{array}{l}\text { Brooks examined safety management and culture in } \\
2002 \text { in a small Australian fishing town [25]. }\end{array}$ & $\begin{array}{l}\text { The simple shared mission was to catch quality fish and sell them to buyers } \\
\text { and the skipper's word was "law." Family continuity over time in the } \\
\text { business and independence was important, risk taking was enculturated } \\
\text { and experience was more important than training. A new deckhand } \\
\text { typically experienced } 10 \text { near misses on their first day on the job, which } \\
\text { dropped dramatically within a week. They assumed that humanity is } \\
\text { subservient to the powerful sea. The workers grasped the majority of } \\
\text { physical risks well but failed to design, plan, or implement risk reduction } \\
\text { measures. The challenge is to build a learning culture with actions based on } \\
\text { risk perceptions. }\end{array}$ \\
\hline $\begin{array}{l}\text { Hávold investigated safety measures among } 9 \\
\text { Norwegian fishers based on initial conditions [26]. }\end{array}$ & $\begin{array}{l}\text { These conditions included the fishery type, type and size of vessel, fisher } \\
\text { time-based experience. He identified the experience of injuries or } \\
\text { near-misses as a learning effect. }\end{array}$ \\
\hline $\begin{array}{l}\text { Christiansen and Hovmand reported on interventions } \\
\text { to protect workers in the Nordic nations [27]. }\end{array}$ & $\begin{array}{l}\text { Nordic fishers rated written materials, guidelines and information low and } \\
\text { preferred direct dialogue, which appear to have greater impact on safety. } \\
\text { They stated that an effective safety culture requires the skipper to take } \\
\text { the lead. }\end{array}$ \\
\hline $\begin{array}{l}\text { Murray et al. interviewed } 55 \text { fishers from small } \\
\text { communities in Newfoundland, Canada about factors } \\
\text { related to injuries and fatalism preceded by high } \\
\text { threat perception and anxiety [28]. }\end{array}$ & $\begin{array}{l}\text { Major worries were the fishery }(n=44 ; 80 \%) \text {, my family }(n=37 ; 67 \%) \text {, } \\
\text { money }(n=34 ; 62 \%) \text {, qualifying for unemployment insurance }(n=25 ; 46 \%) \text {, } \\
\text { damaging gear or boat }(n=23 ; 42 \%) \text {, the weather }(n=17 ; 31 \%) \text {, competition } \\
\text { with other boats }(n=12 ; 22 \%) \text { and argument with the boss or crew } \\
(n=3 ; 4 \%) \text {. }\end{array}$ \\
\hline
\end{tabular}




\subsection{Work Process Risk Factors}

Job hazard analysis is a work process approach for identifying and controlling hazards in aquaculture [29]. In addition, this analysis technique was used for commercial crab fishing to (1) describe steps in a job task; (2) evaluate the risk of an injury in each step; and (3) recommend alternatives to reduce risk for each step in the task [30].

A similar method has been developed for coding of fishing operations and work processes, such as in seining and trawling. An example of work tasks in sequence is: preparing gear and nets (the second most dangerous task) $\rightarrow$ setting gear $\rightarrow$ hauling gear (the most dangerous task) $\rightarrow$ handling fish [31] This system was adapted to non-fatal injuries for the Alaska commercial fishing industry based on United States Coast Guard (USCG) data. Across the different vessel types-gillnet, seine, longline, pot/trap and trawl-the principle work processes were traffic on board, shooting/setting the gear, hauling the gear, handling the gear, processing the catch, handling frozen fish, working in the engine room, mooring, off-duty and other (e.g., firefighting, maintenance, repair) [32].

\subsection{Engineering Control}

"The most effective means of preventing and controlling occupational injuries, illnesses and fatalities is to "design out" hazards and hazardous exposures from the workplace."

_Paul A. Schulte et al., 2008 [33]

Design engineers follow a hierarchy of controls by first eliminating the hazard; failing this, next they guard against the hazard and last warning against the hazard [34]. Elimination of or guarding against the hazard are considered passive controls that do not rely on the potential victim's action, whereas warning - the "be careful" approach-is considered as an active control that depends on human action [35]. Passive controls include eliminating or guarding against hazards.

In 2014, a study reported decreases in commercial fisher fatality rates in northern climates from the 1980s in all countries except Great Britain. There, factors for the increased fatality rate included lone fishers, the high risk of pot fishing, financial pressures and unseaworthy vessels [36]. The retirement of older vessels for new ones likely contributed to the overall decline in fatalities elsewhere [37].

\subsubsection{Fall Overboard and Entanglement Control}

Potential engineering and administrative controls for FOBs are shown in the left column of Table 2 [38]. The right column of the table shows potential protections against and escape options from line entanglements [39].

Table 2. Identified Controls for Fall Overboard Controls and Line Entanglement Prevention and Escape.

\begin{tabular}{ll}
\hline \multicolumn{1}{c}{$\begin{array}{c}\text { Eall Overboard Controls } \\
\text { Engineering Controls } \\
\text { (Alaska fishers) }\end{array}$} & $\begin{array}{c}\text { Line Entanglement Prevention } \\
\text { (Percentages are ratings by Massachusetts Lobstermen) }\end{array}$ \\
\hline Raise gunnels (gunwales) & Washrail (gunwale) above the knee (95\%) \\
\hline Enclose workspaces & Rope locker/bin (a compartment built under the deck (69\%) \\
\hline $\begin{array}{l}\text { Guard against gear entanglement by reducing line coils on the deck } \\
\text { with line bins and lockers }\end{array}$ & $\begin{array}{l}\text { Bucket/pipe as fairlead (rope fed from a bin through a deck } \\
\text { aperture up and into the water; 51\%) }\end{array}$ \\
\hline $\begin{array}{l}\text { Install motor kill switches reachable by the potential victim } \\
\text { Wear a water detection device to cut the motor off }\end{array}$ & Temporary abrasive, such as salt (39\%) \\
\hline $\begin{array}{l}\text { Equip the pilot house with detectors and crew members with } \\
\text { transmitters that sound a warning from a small device activated } \\
\text { when the fall overboard victim is in the water (personal } \\
\text { locator beacon) }\end{array}$ & Safety shut-off cord for engine (35\%) \\
\hline $\begin{array}{l}\text { Install non-slip surfaces, including fiber mats and non-skid grates } \\
\text { Sensor mat for shutting off engine (30\%) }\end{array}$ & $\begin{array}{l}\text { Nonskid mats (95\%) } \\
\text { High traction deck (85\%) }\end{array}$ \\
\hline
\end{tabular}


Table 2. Cont.

\begin{tabular}{ll}
\hline \multicolumn{1}{c}{ Fall Overboard Controls } & \multicolumn{1}{c}{ Administrative controls } \\
\hline \multicolumn{1}{c}{ Conducting survival drills } & Escape options (in order of importance) \\
\hline Assuring the availability and use of PFDs & Wear a knife for cutting the rope \\
\hline Zero tolerance for alcohol consumption & Have a knife mounted in the stern \\
\hline $\begin{array}{l}\text { Carry a diver's knife when line entanglement is a potential exposure } \\
\text { to enable the victim to cut the line }\end{array}$ & Have a line to kill the engine \\
\hline Source: Lucas and Lincoln [38] & Source: Backus et al. [39] \\
\hline
\end{tabular}

\subsubsection{Vessel Stability}

Vessel instability is a recurring theme and fishers have reported that many vessels do not have roll stabilization tanks. Roll stabilization tanks reduce the lateral motion with a tank of water and a central baffle to counter sideways motion of the vessel [27]. Another control against roll is a pair of paravanes drawn through water along the sides of the vessel, preferably from the end of the extended outrigger on a double rig trawl vessel (as shown in Figure 4) [40,41].

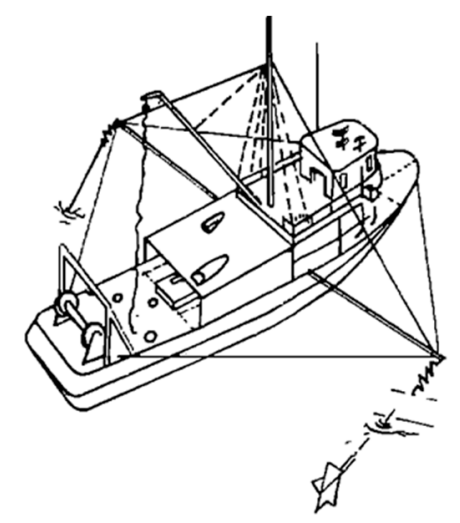

Figure 4. A vessel with paravane stabilizer deployed. Courtesy Alaska Fisheries Development Foundation.

NIOSH engineers also addressed the risk of flooding of the vessel with three designs. One design monitors hatch and door openings to insure they are closed in rough seas. Another design, a Flood-Rate Monitor, tracks the status of water entry into holds and activates pumps to expel excess water. The captain and crew can monitor the flood level risk from a wheelhouse display. The sloshing effect of water in the hold of the vessel can affect the stability (roll) but debris can clog float monitoring devices rendering them ineffective in monitoring changing water levels in the holds. To counter this problem, engineers designed a "Slack Tank Monitor" to measure underwater pressure differences and the sloshing effect in the hold [12].

\subsubsection{Ergonomics}

Regarding musculoskeletal disorders, engineering interventions focused primarily on reducing stress from lifting. One engineering design alleviated ergonomic stress among crabbers in North Carolina [42]. The investigators developed two engineering controls, a crab pot ramp and a crab pot boom as shown in Figure 5. 


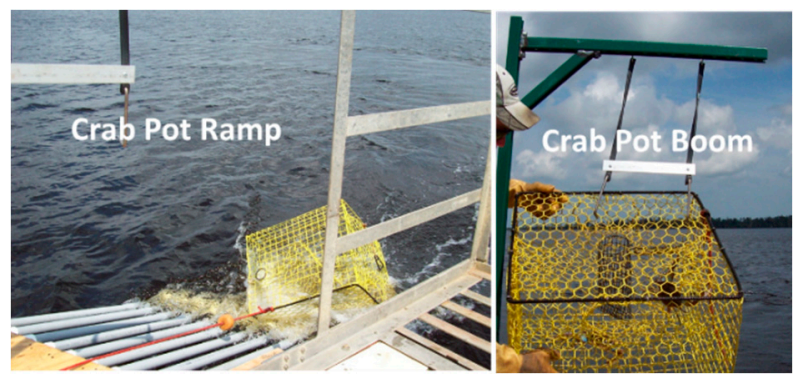

Figure 5. Innovations to mitigate musculoskeletal risk in crab harvesting when lifting pots with a ramp and boom. Courtesy of Gary A. Mirka, Iowa State University.

In tasks such as stacking traps in crab harvesting, icing fish in gillnetting and sorting fish in trawling, ergonomic interventions need to make the best use of the limited space and adjust the work processes to require as little unnecessary lifting as possible [43]. In addition, Nordic fishers have expressed concerns about fatigue, lifting heavy boxes with fish and a need for a box lifter [27].

Fatigue is recognized as a combination of environmental and personal risk factors and one factor is high workloads with frequent manual handling and use of heavy equipment in a wet, slippery and dynamic environment. These conditions affect the fisher's posture, performance, workload, rest and sleep. A study examined self-reported fatigue among 270 Danish fishers (28\% response rate) based on five dimensions: general fatigue (tiredness), physical fatigue (experience related to feeling tired), reduced motivation to start an activity, the reduced motivation and mental fatigue (e.g., reduced concentration). General fatigue was the dominate factor and was closely associated with physical workload. Subjects reported mental fatigue as the least affected of the five factors. Differences were found in vessel types and days at sea and related to the role of automation in reducing fatigue. Trawlers scored lower for fatigue, which were larger vessels than seiners with more automation and seiners scored the highest in general fatigue among different vessel types [44]. Thus, ergonomics that reduces workload through automation is a factor for reduced general fatigue.

\subsubsection{Fall Prevention}

A number of studies have identified slips on the deck as the initial event leading to an injury. Slip resistance of deck surfaces and footwear under different conditions has been evaluated. Even though non-slip coatings are put on steel deck floors, they can be compromised on fishing vessel decks by water, ice, snow, oils and fish/shellfish body tissues and fluids. These compromises may be compounded by sea conditions on deck angles and motions and further affected by the fisher's footwear and dynamics of gait and movement. Three combinations provided good protection against falls: (1) traditional footwear and non-skid paint, (2) grit-impregnated boots and (3) foamed polyurethane paint [45].

\subsubsection{Near Shore Mariculture Innovations}

Clam mariculture involves both offshore and onshore work and the onshore processes may present unique indoor risks. The type of hazards and interventions present in clam mariculture are listed in Table 3. These observations show the value of practical active and passive solutions by clam farmers to protect workers against hazards [46]. 
Table 3. Observations from a case study based on an interview and tour of a clam mariculture farm in South Carolina regarding hazards and simple solutions for the prevention of work-related injuries and diseases, 2008.

\begin{tabular}{|c|c|c|}
\hline Problem & & Intervention \\
\hline - Hyperthermia in onshore greenhouse & $\rightarrow$ & $\begin{array}{l}\text { Limit work in greenhouse clam nursery to } \\
\text { the morning }\end{array}$ \\
\hline - $\quad$ Slippery surface on sloped ramps & $\rightarrow$ & $\begin{array}{l}\text { Nail slats on ramp as footholds; trip hazard was } \\
\text { an unanticipated hazard }\end{array}$ \\
\hline $\begin{array}{l}\text { - Stingray sting on knee led to } 2-3 \text { months unable } \\
\text { to work * }\end{array}$ & $\rightarrow$ & $\begin{array}{l}\text { Wear reef boots that reach above the knee; this } \\
\text { restricted movement so used only in winter } \\
\text { over dry suits }\end{array}$ \\
\hline $\begin{array}{l}\text { - Cuts and scrapes that can lead to infections from } \\
\text { barnacles and clams during harvest }\end{array}$ & $\rightarrow$ & $\begin{array}{l}\text { Wear neoprene wetsuits and gloves } \\
\text { for protection }\end{array}$ \\
\hline - Onshore electrical contact exposure & $\rightarrow$ & $\begin{array}{l}\text { Wear rubber boots and use } \\
\text { ground-fault interrupters }\end{array}$ \\
\hline - $\quad$ Boat floundering risk & $\rightarrow$ & Boats have self-bailing technology \\
\hline - $\quad$ Solar radiation exposure & $\rightarrow$ & Install canopies on boats \\
\hline $\begin{array}{l}\text { - Muscle fatigue and strain when manually } \\
\text { flushing mud from bags during harvest }\end{array}$ & $\rightarrow$ & Use water pump and hose to clean bags \\
\hline - Water pump became a burn hazard & $\rightarrow$ & Wear gloves \\
\hline $\begin{array}{l}\text { - Muscle fatigue and strain when manually lifting } \\
\text { bags onboard boats }\end{array}$ & $\rightarrow$ & $\begin{array}{l}\text { Install and use boom with power pulley and } \\
\text { winch to lift bags onboard }\end{array}$ \\
\hline $\begin{array}{l}\text { - Steel booms easily corroded in salt water } \\
\text { environment creating a breakage hazard }\end{array}$ & $\rightarrow$ & $\begin{array}{l}\text { Replaced corroded booms with stainless } \\
\text { steel booms }\end{array}$ \\
\hline - $\quad$ Slips and trips on deck & $\rightarrow$ & $\begin{array}{l}\text { Use slip resistant boots, ban open footwear } \\
\text { (sandals and flip-flops) }\end{array}$ \\
\hline - $\quad$ Rope burn and scrapes & $\rightarrow$ & Wear gloves \\
\hline
\end{tabular}

Source: Robert Durborow et al. [46]. * Incident occurred on a relative's clam farm in Florida.

\subsection{Personal Protective Equipment: Personal Flotation Devices and Eye UV Protection}

"For example, one fisherman told stories about how some of his colleagues from other vessels, in a joking manner, were shouting 'dog' to him when he chose to make use of a safety line during periods with rough sea."

—Rolf Bye and Gunnar M. Lamvick, 2007 [24]

In 2009, Turner et al. evaluated PFD acceptance in Great Britain (including among fishers) with an aim to increase PFD usage by recreational boaters. The highest PFD use was among kayakers. Using stages of change theory (hazard appraisal $\rightarrow$ decision making $\rightarrow$ initiation $\rightarrow$ adherence), they concluded that the majority of individuals who fail to wear PFDs are in the hazard appraisal and decision-making stages. Therefore, the challenge in encouraging PFD use is to advance people into the adherence stage. The authors recommended that campaigns to increase PFD use provide personal experience of the initial phases of cold water immersion [47]. The four stages leading to death after a FOB in cold Alaska waters are as follows: cold shock $\rightarrow$ swimming failure $\rightarrow$ hypothermia $\rightarrow$ post-recue collapse [48]. Regarding swimming ability, Bye and Lamvick referred to a 2004 study in which $13 \%$ of fishers did not know how to swim [24]. In British Columbia, Brooks et al. found 
swimming failure was the underlying cause of $5.4 \%$ of 128 drownings of commercial fishers over the 1976-2002 period [49], and Marshall et al. found from self-reports of 215 North Carolina fishers in their study that $3.3 \%$ did not know how to swim and $31.2 \%$ had little to adequate swimming ability [22].

Alaskan fishers reported the following complaints when wearing a PFD: PFD weight, bulk, chafing, constriction and interference with work; however, some designs were considered comfortable and fishers on different vessel types had different preferences for the six PFD designs evaluated [50,51]. In another study in Alaska, 146 subjects wore different types of PFDs while fishing over 30 days. The subjects rated the inflatable rubberized neoprene suspender the highest on the 30th day but preferences varied, likely due to differences in fishing equipment, on-deck activities and weather conditions. The authors suggested PFD use must be tailored to the specific vessel types [52]. Table 4 shows the subjects who represent the different gear types, including Dungeless crabbers, their problems with PFD use and their preferences for particular types after working with the different designs. Preferences narrowed to four types of PFDs, two of a foam type and two of an inflatable type as shown in Figure 6 [52].

Table 4. Results of an Evaluation of Different personal flotation devices (PFDs) by Fishers (Subjects) Who Answered a Questionnaire Regarding Barriers to and/or Use of Different Types of Gear and Preferences for Alternative PFD Designs.

\begin{tabular}{|c|c|c|c|c|c|c|}
\hline \multirow{2}{*}{ Subjects } & \multicolumn{4}{|c|}{ Use Reported by Subjects before Test } & \multirow{2}{*}{$\begin{array}{l}\text { Reasons for Not Wearing } \\
\text { PFDs }\end{array}$} & \multirow{2}{*}{$\begin{array}{c}\text { Preferred PFDs after } \\
\text { Use }\end{array}$} \\
\hline & Always & Never & Sometimes & Frequently & & \\
\hline Trawlers & $51 \%$ & $12 \%$ & $11 \%$ & $26 \%$ & - entanglement hazard & $\begin{array}{ll}\text { - } & \text { Mustang } \\
\text { - } & \text { Regatta } \\
\text { - } & \text { Stearns Inflatable } \\
\text { - } & \text { Sterns vest }\end{array}$ \\
\hline Crabbers & $22 \%$ & $16 \%$ & $50 \%$ & $12 \%$ & $\begin{array}{ll}\text { - } & \text { uncomfortable } \\
\text { - } & \text { interfere with work } \\
\text { - } & \text { entanglement hazard }\end{array}$ & $\begin{array}{l}\text { - } \quad \text { Mustang } \\
\text { - } \quad \text { Stearns Inflatable }\end{array}$ \\
\hline Longliners & - & $64 \%$ & $31 \%$ & $5 \%$ & $\begin{array}{l}\text { - } \quad \text { snagging on longline } \\
\text { working near gear on } \\
\text { crowded deck }\end{array}$ & - $\quad$ Mustang \\
\hline Gillnetters & $5 \%$ & $55 \%$ & $30 \%$ & $10 \%$ & $\begin{array}{l}\text { - } \\
\text { - } \\
\text { - } \\
\text { - } \\
\text { entanglanglement hazard }\end{array}$ & $\begin{array}{l}\text { - } \quad \text { Regatta } \\
\text { - } \quad \text { Stearns Inflatable }\end{array}$ \\
\hline $\begin{array}{l}\text { Dungeness } \\
\text { crabbers }\end{array}$ & $6 \%$ & $51 \%$ & $33 \%$ & $5 \%$ & $\begin{array}{ll}\text { - } & \text { lack of comfort } \\
\text { - } & \text { entanglement hazard } \\
\text { - } & \text { movement interference }\end{array}$ & $\begin{array}{l}\text { - } \quad \text { Mustang } \\
\text { - } \quad \text { Stearns vest }\end{array}$ \\
\hline
\end{tabular}

Positive Features Expressed by Subjects Regarding Different PFDs

- Regatta raingear with built-in foam flotation-light weight, does not limit motion, does not interfere with work, easy to keep clean, non-chafing

- Stearns Inflatable Suspenders-does not snag on gear, easy to keep clean, does not limit motion

- Mustang Inflatable Suspenders (MD3188)—does not snag on gear, easy to put on, comfortable to wear (not tight or bulky), did not constrict motion. Did not interfere with their work, non-chafing

- Stearns Foam Work Vest-non-chafing, light weight, comfortable 

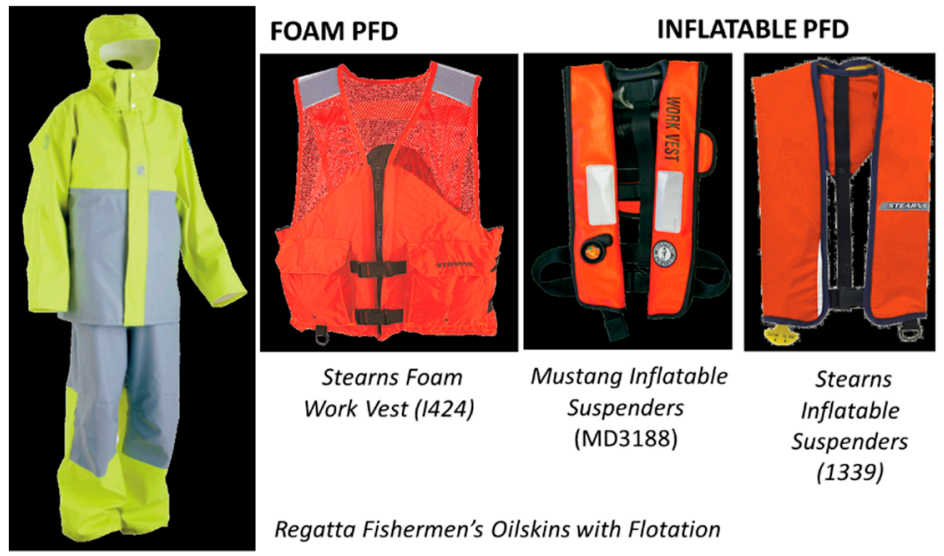

Regatta Fishermen's Oilskins with Flotation

Figure 6. The four most popular PFDs evaluated by fishers across the use of five different fishing gear, 2009, adapted from NIOSH images. Open source and approval from Jennifer Lincoln, NIOSH [52].

In a Massachusetts study, fishing captains and sternmen reported rarely donning PFDs. Reasons for PFD disuse were discomfort, risk acceptance, social stigma and anticipating a lingering death when a FOB is unnoticed. Discomfort factors included bulkiness, interference with work and a higher likelihood of entanglement. The social stigma factor centered on a norm of regular disuse, that when PFDs are used they appear "strange," and coworker perceptions that PFD use indicates inexperience. Recommendations included improving PFD designs and trials for worker satisfaction, making designs more socially acceptable, increasing confidence of a rescue in the event of a FOB through the use of personal locator beacons and using an Emergency Position Indicating Radio Beacon (EPIRB) to alert the USCG of a sinking vessel and the need and location for a rescue [53].

A similar study is underway in the Northeast lobster fishery to redesign the PFD for acceptance by dealing with discomfort, interference with work and potential safety hazards (e.g., entanglements). In January 2017, 80 lobster fishers started wearing eight different PFD models to provide feedback on design changes [54].

Ultraviolet (UV) radiation from the sun has been associated with cataract formation and other eye disorders. In 1988, a study was conducted of the use of wide brimmed hats for reducing UV exposure. They measured UV exposure to 81 subjects with and without wide-brimmed hats over a 6-month period, totaling 178 samples. The subjects harvested oysters and crabs. Brimmed hats provided significant eye protection from UV exposure across all subjects as shown in Figure 7 [55].

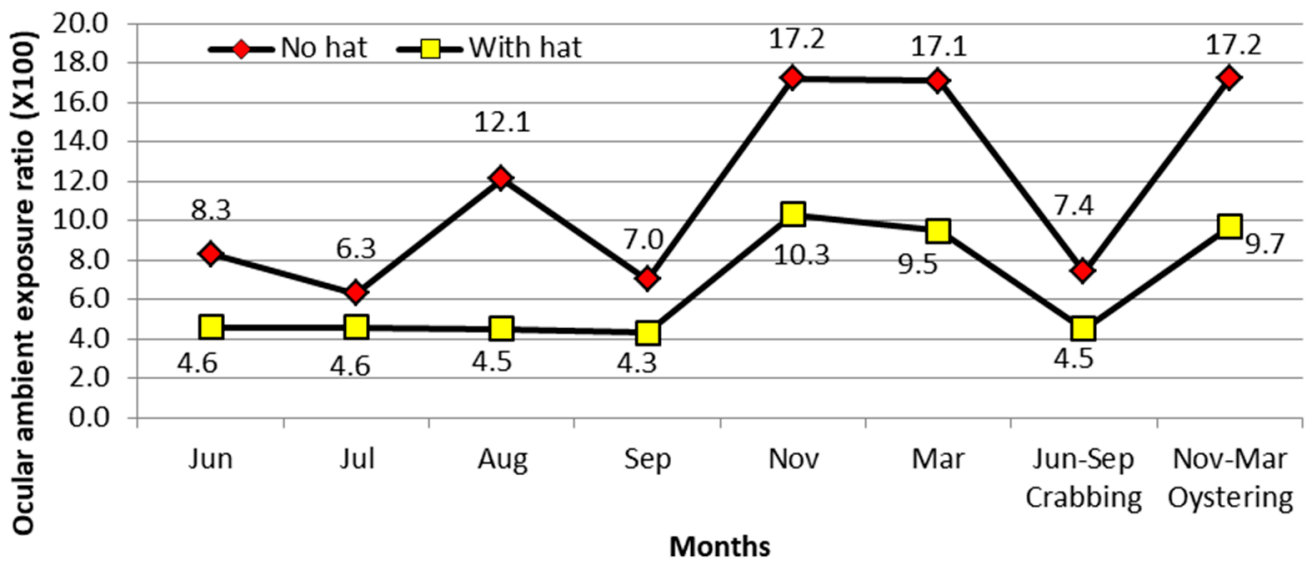

Figure 7. Ocular UV measurements without hats (mean $=11.2 \pm 8.5, n=28$ ) and with hats. (mean $=7.2 \pm 7.1, n=148)$ [55]. 


\subsection{Incentives}

A 1971 USCG study concluded that a regulated fishing safety program could prevent $72 \%$ of fisher fatalities but it determined that such a program would create an unsustainable financial hardship on the industry [56]. An Individual Fishing Quota (IFQ) system is based on the amount of fish caught over a longer period of time than a fishing derby (seasonal closures) and therefore, reduces the amount of time spent fishing when fatigued or fishing when conditions are dangerous. Under the IFQ system, fishers were free to choose not to fish during dangerous high winds and simply catch their quota later when conditions are safer.

An IFQ system based on the amount of fish mitigates these risks. As an example, under an IFQ system on the US West Coast, fishing on high wind days was reduced by $79 \%$. High winds correlate with higher waves and stormy conditions. The USCG saw an $83 \%$ decrease in incident rate in this fishery after the IFQ system was used rather than season compression [57]. A study examined data in the GoM where a shift was made from the seasonal closures to IFQs for two reef fish, grouper and red snapper. Data from before and after the switch for these fisheries showed a 19\% drop in the fatality rate after the change and associated this decrease with taking less risky trips during adverse weather conditions [58].

Törner et al. launched a program for promoting safety measures on 101 Swedish fishing vessels. They used a cost-benefit approach for the business, the victim and co-workers as an incentive for the adoption of safety or ergonomic measures. Inspections identified 36 deficiency types totaling 1427 specific deficiencies. In a 6-month follow-up, 160 (11\%) safety measures had been adopted to mitigate the deficiencies [59].

\subsection{Training}

Training has been used to develop a culture of safety among Massachusetts fishers. A recent tragedy, community leadership and boat captain encouragement facilitated training attendance. About 700 fishers attended two-week hands-on training courses [60].

A safety training program in Alaska was found to be effective when comparing training between decedents with survivors of vessel disasters. However, survival skills eroded over time, thus refresher courses are needed, and monthly drills are a way to maintain survival skills [61]. Safety training received a boost from the National Oceanic and Atmospheric Administration's (NOAA) fishery observer program. NOAA observers monitor catches onboard the vessels while fishing occurs [62]. Observers are not members of the crew but are, nonetheless, at risk of dangers on the vessel and undergo survival training. In addition, the USCG inspects the vessels and conducts monthly emergency drills for compliance with regulations for the safety of the observer and indirectly, for the crew [63].

\subsection{Narrative Outreach}

"This approach basically argues that human beings are natural storytellers and that the exchange of stories permeates our everyday social interaction"

$$
\text { -Michael Murray, } 2000 \text { [63] }
$$

Incorporating cultural aspects of commercial fishing into the educational process was found to authenticate the learning experience. The need is for training that is focused, exploratory and interactive with less emphasis on the instructor providing knowledge. The aim is to connect new knowledge with lived experience facilitated by the use of narrative [64].

Interviews of more than 40 Newfoundland fishers in Canada resulted in narratives about their perceptions of incident causes and possible means to prevent injuries and descriptions of resulting fatalities and/or other adverse events and their perceptions of potential safety measures. The fishers were eager to recount their tales and concluded that narratives rather than didactic instruction provided a teaching opportunity for action [63]. 


\section{Discussion}

Our two previous reviews identified studies that examined safety and health risks faced by fish harvesters. This third review evaluates countermeasures. In combination, these three reviews focus on three criteria: (1) frequency of the condition; (2) severity in the individual case and (3) preventability. Below, we discuss the limitations and implications of this review.

\subsection{Limitations}

This is a narrative review and not a systematic review. Thus, the findings are generalized and descriptive and do not necessarily reflect statistically significant results or countermeasures. Another limitation is the recognized serious underreporting of nonfatal injuries regarding small, sometimes single operator fishing vessels. There was serious underreporting of nonfatal injuries and illnesses across all vessel types but more so among small, sometimes single operator, fishing vessels. In addition, there is the abundance of literature we cited from outside of the GoM but nevertheless, elements of the literature inform our research on GoM fishers with cross-regional patterns and investigation and intervention methods. This review included non-refereed journal articles but the government documents and conference proceedings reviewed provide important information regarding innovative countermeasures that may lead to studies of effectiveness and the eventual reduction in occupational injuries and diseases [65].

\subsection{The Implications for Countermeasures}

Many risks to health and safety face GoM fishers that may result in adverse outcomes: traumatic injuries, FOB and onboard injuries, back disorders, traumatic eye injuries and ocular exposures to ultraviolet radiation, hearing loss, breathing and skin effects and fatigue-related injuries [9]. The fishing community accepts risk as natural and normal, conditioned as a birthright from early in life and that fishing is an economic necessity. Independence from authority is valued. Experience drives safe behavior and the captain controls the vessel. The challenge is to change acceptance to less risky personal behaviors through education and investment. A summary of countermeasures is listed in Table 5.

Table 5. Summary of potential interventions to prevent injuries, disabilities and diseases experienced by fishers in the Gulf of Mexico.

\begin{tabular}{|c|c|}
\hline Health Effects/Hazards & Potential Interventions \\
\hline Fatigue & $\begin{array}{l}\text { Avoid work to exhaustion, get sleep, sleep without interruption, use caffeine, control } \\
\text { sea-sickness, noise control, automate workload processes }\end{array}$ \\
\hline Fatalities & $\begin{array}{l}\text { Wear PFDs in skiffs or on deck, use personal locator beacons and EPIRBs, fish in fair weather, } \\
\text { conduct drills, maintain USCG sticker on vessel, learn to swim, know how to issue a Mayday } \\
\text { call, know CPR and resuscitation, increase vessel stability }\end{array}$ \\
\hline Non-fatal injuries & $\begin{array}{l}\text { Guards on winches, use high friction footwear and decks, wear and maintain gloves, reduce } \\
\text { clutter on deck, know first aid }\end{array}$ \\
\hline Musculoskeletal disorders & $\begin{array}{l}\text { Avoid heavy lifting (by using other lift means or with help), twisting, repetitive motions; teach } \\
\text { captains ergonomic principles to encourage innovations, job redesign }\end{array}$ \\
\hline Biological hazards & $\begin{array}{l}\text { Recognize and avoid contact with poisonous and toxic aquatic species, treat toxic shock and } \\
\text { stingray stings, wear protective clothing }\end{array}$ \\
\hline Skin and eye hazards & $\begin{array}{l}\text { Prevent sunburn with sun screen, wear broad rimed hat to protect eyes and lips from sunlight, } \\
\text { avoid skin contact with fish, wear UV protected glasses }\end{array}$ \\
\hline Breathing hazards & $\begin{array}{l}\text { Work in ventilated areas when handling fish, use protective gear around chemicals and fish } \\
\text { bioaerosols }\end{array}$ \\
\hline Hearing hazards & Wear hearing protectors in the engine room, avoid carbon monoxide exposure \\
\hline Dangerous work processes & Use job hazard analysis, redesign tasks to avoid hazards \\
\hline Lack of safety culture & $\begin{array}{l}\text { Teach with participatory hands-on methods, share stories, use pictures, consider family } \\
\text { involvement, focus on captains and unacceptable risks, recognize and share innovations }\end{array}$ \\
\hline Mariculture hazards & $\begin{array}{l}\text { Wear hearing protection around noise, avoid electrical hazards (use ground fault interrupters), } \\
\text { avoid falls and falling objects, ban open footwear, schedule work time to avoid heat stress }\end{array}$ \\
\hline
\end{tabular}




\subsubsection{Fatality Hazards}

FOB-related fatalities are the most severe and a frequent safety problem in the GoM followed in prevalence by vessel disasters. The literature addressed countermeasures to deaths from FOB by encouraging fishers to wear PFDs, not working alone on the deck, wearing personal locator beacons to signal the helmsman of an overboard fisher, ladders for boarding the vessel, and swimming ability. Personal locator beacons need to be evaluated for killing the motor on a lone fisher's skiff in the event of a FOB, alerting the helmsman of a FOB on vessels and alerting the USCG of a FOB. Much research was conducted about acceptability of PFDs in the Northern States but regarding the GoM, a factor is discomfort of wearing PFDs in warm climates. Another barrier is the stigma of wearing PFDs as not manly but this runs counter to the rough and tough look of those in the NIOSH Alaska cohorts, which could help to overcome this perception. This stigma is also affected by the anticipation of a slow death after a FOB when lost at sea, which the personal locator beacons could help avoid.

Problems of clutter on deck pose trip hazards. Installing and using boxes to hold the ropes and lines could abate this hazard. Guards have been designed to cover winches to prevent entanglements but their use awaits acceptance. Regarding vessel floundering, the attachment point on the vessel can be changed so a net obstruction does not pull down the end of the vessel underwater and sink it. Roll stabilizers such as paravanes can counter wave motion as does roll stabilization tanks. Innovations in monitors for open hatches and forces of sloshing water in the holds can help counter floundering of the vessel.

Reported environmental factors that include the need for major wave prediction [66] to prevent weather-related vessel disasters $[67,68]$ deserve more attention in the literature. Wind has been identified as a predictor for dangerous weather. A shift in some fisheries from time-limited fishing "derbies" no matter the weather to an IFQ system made it possible to pick fair weather for fishing and not overload the vessel because of time demands [69]. While there are other risk factors such as noise and work exhaustion and sea-sickness that are associated with fatigue, the principle intervention for fatigue reduction is to increase the quality and quantity of sleep [70].

The Haddon matrix offers a way to bring the environment into the picture. It is a qualitative epidemiology approach to organize the information useful for attacking the safety and health hazards associated with GoM commercial fishing and aquaculture hazards [71,72]. Table 6 shows a simulation of the matrix $[73,74]$.

Table 6. An exemplar scenario of the application of the Haddon Matrix used to identify risk factors regarding a fatal incident and for setting intervention priorities.

\begin{tabular}{llll}
\hline \multicolumn{1}{c}{ Factor } & \multicolumn{1}{c}{ Pre-Event } & \multicolumn{1}{c}{ Event } & \multicolumn{1}{c}{ Post-Event } \\
\hline Technology & $\begin{array}{l}\text { Skiff without personal activator to } \\
\text { activate a kill switch, Stowed PFD } \\
\text { Priority: PFD available, PLB and } \\
\text { engine kill switch }\end{array}$ & $\begin{array}{l}\text { Motor keeps skiff moving } \\
\text { from fisher } \\
\text { Priority: PLB and engine } \\
\text { kill switch }\end{array}$ & Skiff motors far from victim \\
\hline Environment & $\begin{array}{l}\text { Physical: Storm, wind, deep water } \\
\text { Priority: Fish in fair weather }\end{array}$ & Physical: High waves, wind & $\begin{array}{l}\text { Physical: High waves, wind } \\
\text { Social: No insurance } \\
\text { Priority: Insurance availability }\end{array}$ \\
\hline & $\begin{array}{l}\text { Working alone, not wearing PFD, } \\
\text { poor swimmer } \\
\text { Pritity: Swimming skills, PFD use }\end{array}$ & Fall overboard & Victim drowned, lost at sea \\
\hline $\begin{array}{l}\text { PFD = personal flotation device; PLB = personal locator beacon. Source: Adapted from Quan \& Osborne 2016 [73] } \\
\text { and Myers 2015 [74]. }\end{array}$
\end{tabular}

\subsubsection{Nonfatal Injuries}

The deck is the dominant location of nonfatal injuries, and across much of the literature, sources of the most serious injuries are falls, machinery (e.g., winch entanglements) and struck-by injuries. Line entanglement is another serious hazard on the deck. Some interventions to control nonfatal injuries are similar to those for fatality prevention, such as FOB protection and placing guards on the 
winches or permanent guides for the line. Keeping the deck clear to avoid trips, dealing with slippery surfaces, wearing appropriate footwear and keeping potential moving and falling objects secure are also important preventive measures.

\subsubsection{Musculoskeletal Disorder Hazards}

Many studies around the world address the problem of musculoskeletal disorders associated with fishing. The universal problem is back pain, especially in the lumbar region. Other body parts affected include the shoulders, hands and wrists, and elbows and knees. Finding ways to reduce heavy lifting is critical. Researchers suggested capitalizing on the inventiveness of fishers by teaching them the principles of ergonomics to enable them to innovate practical ways to make work easier and more efficient. Engineering designs or fisher innovations can provide alternatives to manual lifting.

\subsubsection{Biological Hazards}

Avoiding animal bites and stings is important as is being able to identify and avoid contact with marine venomous animals such as stingrays, the Portuguese man-of-war and certain jellyfish and marine snails. Immediate treatment for some toxic stings is critical, and informing emergency responders and crew members of anti-venom administration, anaphylaxis treatment and surgery as well as long-term treatment is important [75].

\subsubsection{Skin and Eye Hazards}

Skin hazards include some of the biological hazards, such as allergic contact dermatitis. Irritant contact dermatitis is another skin condition. Gloves are a good protection against both hazards. Skin cancer is an obvious hazard but surprisingly, people who are exposed continually over a long period develop protective barriers to cancer called photoprotection [23]. However, sun burns need to be avoided (e.g., new deckhands) with sunscreen and clothing and lips and eyes need protection, such as with wide-brimmed hats.

\subsubsection{Hearing Hazards}

Noise from vessel engines is a uniform hazard for all motorized fishing vessels around the world. Traditional hearing protectors should be worn near running engines. Dampening some of the engine vibration may be helpful and noise dampening needs to be considered in the sleeping quarters [76]. Carbon monoxide exposure should be avoided. Engine maintenance may reduce noise levels.

\subsubsection{Breathing Hazards}

The principal respiratory hazard to fishers was thought to be protein aerosols emitted from fish but work on deck provides protective ventilation. Gutting fish (and perhaps deheading) shrimp off the deck also poses a respiratory hazard. Other respiratory hazards include exposure to engine exhaust, seafood preservation materials and anti-fouling applications on the vessels. Divers' air source needs to avoid vessel exhaust [77].

\subsubsection{Work Process Risk Factors}

As described earlier, the general steps in the fishing process are (1) preparing gear and nets; (2) setting gear; (3) hauling gear and (4) handling fish [36]. Building a flowchart of sub-processes aids in identifying high-hazard tasks. In effect, it is a logic diagram and illustrates that much of the work is repetitive (e.g., hauling pots or removing shrimp heads). Safety professionals use job hazard analysis to define the sequence of tasks in a job, the hazards associated with each task and possible interventions to prevent or protect against each hazard. For ergonomists, this approach is critical for understanding the combination of stresses on a worker. 


\subsubsection{Safety Culture}

Research into the fishing culture indicates that, in stark contrast with the injury data, fishers believe their work is safe, even though they are aware of the hazards. Moreover, they learn by experience. Several studies made the point that the captain's word is law at sea and the captain is an opportune change agent for a commitment to and competency for safety. An intervention strategy suggested by some researchers was to use a narrative rather than a didactic approach for training that emphasizes the use of stories to teach. In some studies, the fishers valued hands-on training over classroom training and some fishers expressed a desire for using pictures for training. More attention is needed to consider the members of the whole family in any learning agenda like the Fishing Partnership Program in Massachusetts [78].

\section{Conclusions}

Fatalities are the most severe injury experienced by the GoM fish harvester community and the most frequent cause of these fatalities is FOB and vessel disasters. The principle intervention for FOB is donning PFDs and for vessel disaster is warning other vessels of potential collisions. Behavioral barriers diminish PFD use but current studies aim to resolve these barriers. Personal locater beacons to alert the helmsman and the USCG or to stop the engine has promise to protect lives but needs evaluation, perhaps by NIOSH as personal protective equipment. No study of nonfatal injury severity and frequency has been conducted in the GoM but the USCG documents cases by the Abbreviated Injury Scale, which could provide insight into both measures. These injuries include slip and fall, entanglement and struck-by injuries, which occur predominately while working with gear on the deck. Interventions include providing winch guards and non-slip surfaces and footwear.

The literature was rife with cases of musculoskeletal disorders and the interventions included ergonomic-based job redesign and training. Another frequent health effect was injury and poisoning by animal contact. Gloves protect against injury and contact dermatitis. Wearing ear plugs or muffs provides protection against the most prevalent source of hazardous noise, the vessel engine. Protection of the eyes and lips and skin from sunburn against sun rays is important to prevent cancer. Natural ventilation on deck protects fishers from respiratory hazards; in enclosed areas, exposure to engine exhaust and protein aerosols pose hazards to the lungs, thus good ventilation is important.

Fishers accept risks as normal. Thus, the challenge is to improve fisher competence and commitment to improve the safety culture, particularly among vessel captains. Involvement of fishers in identifying hazards and interventions to improve the safety culture is critical. Researchers point to using captains' practical innovation capacity as an intervention by teaching them ergonomic principles. This involvement also includes identifying interventions in place to be shared more broadly and encouraging adoption of both active and passive controls. Enculturating a safety checklist with the fishers that would include obvious protections (e.g., zero-alcohol tolerance, no open footwear) may help.

Author Contributions: M.L.M. conducted the search and initial composition of the manuscript. R.M.D. and A.S.K. provided ongoing reviews and edits of the manuscript, and A.S.K. directed the project.

Funding: The US National Institute for Occupational Safety and Health, Centers for Disease Control and Prevention funded this research through a grant to the University of Florida Southeastern Coastal Center for Agricultural Safety and Health, Gainesville, Florida, USA.

Acknowledgments: We acknowledge Christina McManus, Science and Technology Editor, Kentucky State University, Frankfort, Kentucky, USA for her technical edit of this manuscript.

Conflicts of Interest: The authors declare no conflicts of interest. 


\section{Appendix A. Literature Reviewed}

Table A1. The geographic origin (area) of the study, the intervention and a reference to the literature source, $n=52$.

\begin{tabular}{|c|c|c|}
\hline Area & Intervention & Source \\
\hline \multicolumn{3}{|c|}{ Gulf of Mexico USA, $n=11$} \\
\hline Fishing & Slip resistant surfaces * & Wallace, 2003 [45] \\
\hline Shrimp & Education/training & Carruth et al., 2010 [7] \\
\hline Shrimp & Demographic factors & Levin et al., 2010 [9] \\
\hline Shrimp & Training partnerships & Levin et al., 2012 [8] \\
\hline Fishing & Winch safety & Lucas et al., 2013 [11] \\
\hline Fishing & Ergonomics training & Bloswick and Dzugan, 2014 [15] \\
\hline Fishing & Ergonomics training & Bloswick and Dzugan, 2014 [16] \\
\hline Shrimp & Safety & Levin et al., 2016 [10] \\
\hline Shrimp & Winch guards & Lincoln et al., 2017 [14] \\
\hline Shrimp & PFD acceptance & Carruth et al., 2017 [17] \\
\hline Reef Fish & Individual fishing quotas & Marvasti and Dakhlia, 2017 [58] \\
\hline \multicolumn{3}{|c|}{ Atlantic Coast USA, $n=8$} \\
\hline Fishing & Ergonomics & Fulmer, 2003 [43] \\
\hline Fishing & Entanglement prevention & Backus et al., 2003 [39] \\
\hline Fishing & Culture, insurance & Marshall et al., 2004 [22] \\
\hline Fishing & Training & Hall-Arber and Mrakovcich, 2008 [60] \\
\hline Crabbing & Ergonomic interventions & Mirka et al., 2011 [42] \\
\hline Lobster (MA) & PFD use & Sorenson, 2015 [53] \\
\hline Lobster (MA) & PFD designs & Weil, 2017 [54] \\
\hline Clam Farming & Innovations & Durborow et al., 2018 [46] \\
\hline \multicolumn{3}{|c|}{ Alaska USA, $n=9$} \\
\hline Fishing & Job hazard analysis & Bloswick et al., 2003 [30] \\
\hline Fishing & Engineering and administrative controls & Lucas and Lincoln, 2007 [38] \\
\hline Fishing & Winch stop switches & Lincoln et al., 2008 [12] \\
\hline Fishing & Training efficacy & Dzugan, 2010 [56] \\
\hline Fishing & Personal flotation device comfort & Lucas et al., 2012 [48] \\
\hline Fishing & Personal flotation device use & Lucas et al., 2013 [50] \\
\hline Fishing & Training efficacy & Dzugan, 2014 [56] \\
\hline Fishing & PFD effectiveness & Lucas et al., 2015 [51] \\
\hline Fishing & Engineering designs & NIOSH, 2016 [13] \\
\hline Fishing & Work process & Syron et al., 2016 [32] \\
\hline \multicolumn{3}{|c|}{ Australia, $n=1$} \\
\hline Fishing & Safety culture & Brooks, 2005 [25] \\
\hline \multicolumn{3}{|c|}{ Northern Europe, $n=10$} \\
\hline Fishing & Safety measures, cost & Törner et al., 1999/2000 [59] \\
\hline Fishing & Roll stabilizers & Webster et al., 2003 [40] \\
\hline Fishing & Rick control attitude & Törner and Eklöf, 2003 [21] \\
\hline Fishing & Process coding & Jensen et al., 2005 [31] \\
\hline Fishing & Safety culture & Bye and Lamvick, 2007 [24] \\
\hline Boaters and Fishers & PFD use & Turner et al., 2009 [47] \\
\hline Fishing & Safety culture & Hávold, 2010 [26] \\
\hline Fishing & Fatality trends & Jensen et al., 2014 [36] \\
\hline Fishing & Interventions, safety culture & Christiansen and Hovmand, 2017 [27] \\
\hline Fishing & Fatigue & Remmen et al., 2017 [44] \\
\hline \multicolumn{3}{|c|}{ Other, $n=13$} \\
\hline Fishing & Vessel age & Meek, 1985 [37] \\
\hline Fishing & Threat perception & Murray et al., 1997 [28] \\
\hline Fishing & Paravanes & Bass, 1998 [41] \\
\hline Fishing & Threat perception & Murray, $2000[63]$ \\
\hline Fishing & Culture & Matheson et al., 2001 [19] \\
\hline Fishing & Narrative curricula & Howe, 2003 [64] \\
\hline Canada & Injury experience & Acheson, 2003 [20] \\
\hline Fishing & Ergonomics & Fulmer, 2003 [43] \\
\hline Canada & Swimming failure & Brooks et al. 2005 [49] \\
\hline Brazil & Culture, photoprotection & Bezerra et al., 2011 [23] \\
\hline Aquaculture & Job hazard analysis & Myers and Durborow, 2012 [29] \\
\hline Fishing & US observer program & Craig, 2014 [62] \\
\hline US & Quota system & Pfeiffer and Gratz, 2016 [57] \\
\hline
\end{tabular}

PFD: Personal Flotation Device; NIOSH: National Institute for Occupational Safety and Health. * Results of this laboratory study applied beyond the GoM. 


\section{References}

1. Myers, M.; Durborow, R.; Kane, A. Gulf of Mexico seafood harvesters: Part 1. Occupational Injury and Fatigue Risk Factors. Safety 2018, 4, 31. [CrossRef]

2. Myers, M.; Durborow, R.; Kane, A. Gulf of Mexico seafood harvesters: Part 2. Occupational health-related risk factors. Safety 2018, 4, 27. [CrossRef]

3. Syron, L.; Case, S.; Kloczko, D.; Mason, K.; Lucas, D.; Teske, T. Commercial Fishing Fatality Summary: Gulf of Mexico Region. NIOSH, CDC, USA, Publication No. 2017-174, 2017 July. Available online: https: / /www.cdc.gov/niosh/docs/2017-174/pdf/2017-174.pdf (accessed on 11 October 2017).

4. National Institute for Occupational Safety and Health. List of Journal Articles on Occupational Safety in the Fishing Industry 1954-2012. Centers for Disease Control, USA, Undated. Available online: https:/ /www. cdc.gov/niosh/topics/fishing/pdfs/Fishing_Safety_Bibliography_1954-2012.pdf (accessed on 7 July 2017).

5. Lincoln, J.M.; Hudson, D.S.; Conway, G.A.; Pescatore, R. (Eds.) Proceedings of the International Fishing Industry Safety and Health Conference, Woods Hole, MA, USA, 23-25 October 2000. Available online: https: / www.cdc.gov/niosh/docs/2003-102/pdfs/2003-102.pdf (accessed on 12 November 2017).

6. Mode, N.A.; Wopat, P.; Conway, G.A. (Eds.) Proceedings of the Second International Fishing Industry Safety and Health Conference, Sitka, AK, USA, 22-24 September 2003; DHHS publication No. (NIOSH) 2006-114, April 2006. Available online: https:/ / stacks.cdc.gov/view/cdc/6721 (accessed on 12 November 2017).

7. Carruth, A.K.; Levin, J.L.; Gilmore, K.; Bui, T.; Gallardo, G.; Evert, W.; Sealey, L. Cultural influences on safety and health education among Vietnamese fishermen. J. Agromed. 2010, 15, 375-385. [CrossRef] [PubMed]

8. Levin, J.L.; Gilmore, K.; Carruth, A.; Wickman, A.; Shepherd, S.; Gallardo, G.; Nonnenmann, M. Helping Gulf shrimpers adopt safety measures: Importance of partnerships and research to practice. J. Agromed. 2012, 17, 15-21. [CrossRef] [PubMed]

9. Levin, J.L.; Gilmore, K.; Shepherd, S.; Wickman, A.; Carruth, A.; Nalbone, J.T.; Gallardo, G.; Nonnenmann, M.W. Factors influencing safety among a group of commercial fishermen along the Texas Gulf Coast. J. Agromed. 2010, 15, 363-374. [CrossRef] [PubMed]

10. Levin, J.L.; Gilmore, K.; Wickman, A.; Shepherd, S.; Shipp, E.; Nonnenmann, M.; Carruth, A. Workplace safety interventions for commercial fishermen of the Gulf. J. Agromed. 2016, 21, 178-189. [CrossRef] [PubMed]

11. Lucas, D.; Woodward, C.; Lincoln, J. Fatal and nonfatal injuries involving fishing vessel winches-Southern shrimp fleet, United States, 2000-2001. MMWR 2013, 62, 157-160.

12. Lincoln, J.M.; Lucas, D.L.; McKibbin, R.W.; Woodward, C.C.; Bevan, J.E. Reducing commercial fishing deck hazards with engineering solutions for winch design. J. Saf. Res. 2008, 39, 231-235. [CrossRef] [PubMed]

13. National Institute for Occupational Safety and Health. Commercial Fishing Safety: Engineering Innovations. 8 June 2015. Available online: https: / / www.cdc.gov/niosh/topics/fishing/engineering.html (accessed on 9 July 2017).

14. Lincoln, J.M.; Woodward, C.C.; King, G.W.; Case, S.L.; Lucas, D.L.; Teske, T.D. Preventing fatal winch entanglements in the US southern shrimp fleet: A research to practice approach. J. Saf. Res. 2017, 60, 119-123. [CrossRef] [PubMed]

15. Bloswick, B.S.; Dzugan, J. Ergonomics training in the commercial fishing industry: Emerging issues and gaps in knowledge. J. Agromed. 2014, 19, 87-89. [CrossRef] [PubMed]

16. Bloswick, D.S.; Dzugan, J. Development of an Ergonomics Training Program for the Commercial Fishing Industry: Charges, Challenges and Changes. J. Agromed. 2014, 19, 203. [CrossRef]

17. Carruth, A.; Levin, J.; Creel, E.; Sorensen, J.; Lincoln, J. Commercial Fishing Safety in the Gulf of Mexico and the Southwest Ag Center: The Decade in Review. In Proceedings of the STTI 28th International Nursing Research Congress, Dublin, Ireland, 27-31 July 2017.

18. Manuele, F.A.; Main, B.W. On acceptable risk: What level of risk if any, is acceptable in the workplace? EHS Today. 8 January 2002. Available online: http://www.ehstoday.com/news/ehs_imp_35066 (accessed on 2 September 2017).

19. Matheson, C.; Morrison, S.; Murphy, E.; Lawrie, T.; Ritchie, L.; Bond, C. The health of fishermen in the catching sector of the fishing industry: A gap analysis. Occup. Med. (Lond.) 2001, 51, 305-311. [CrossRef] [PubMed] 
20. Acheson, V. Fishers' attributed causes of accidents and implications for prevention education. In Proceedings of the Second International Fishing Industry Safety and Health Conference, Sitka, AK, USA, 22-24 September 2003; DHHS (NIOSH) Publication No. 2006-114, National Institute for Occupational Safety and Health, Centers for Disease Control, USA. 2003; pp. 225-236. Available online: https:/ / www.cdc.gov/niosh/docs / 2006-114/pdfs / 2006-114.pdf (accessed on 28 May 2017).

21. Törner, M.; Eklöf, M. Participatory Analysis of Accidents. Risk Perception among Fishermen and Control of Risks through Participatory Analysis of Accidents and Incidents. In Proceedings of the International Fishing Industry Safety and Health Conference, Woods Hole, MA, USA, 23-25 October 2000; Lincoln, J.M., Hudson, D.S., Conway, G.A., Pescatore, R., Eds.; National Institute for Occupational Safety and Health, Centers for Disease Control and Prevention, 2003; pp. 237-241. Available online: https:/ /www.cdc.gov/ niosh/docs/2003-102/pdfs/2003102.pdf (accessed on 28 May 2017).

22. Marshall, S.W.; Kucera, K.; Loomis, D.; McDonald, M.A.; Lipscomb, H.J. Work related injuries in small scale commercial fishing. Inj. Prev. 2004, 10, 217-221. [CrossRef] [PubMed]

23. Bezerra, S.M.; Sotto, M.N.; Orii, N.M.; Alves, C.; Duarte, A.J. Effects of long-term chronic exposure to sun radiation in immunological system of commercial fishermen in Recife, Brazil. An. Bras. Dermatol. 2011, 86, 222-233. [CrossRef] [PubMed]

24. Bye, R.; Lamvick, G.M. Professional culture and risk perception: Coping with danger on board small fishing boats and offshore service vessels. Reliab. Eng. Syst. Saf. 2007, 92, 1756-1763. [CrossRef]

25. Brooks, B. Not drowning, waving! Safety management and occupational culture in an Australian commercial fishing port. Saf. Sci. 2005, 43, 795-814. [CrossRef]

26. Hávold, J.I. Safety culture aboard fishing vessels. Saf. Sci. 2010, 48, 1054-1061. [CrossRef]

27. Christiansen, J.M.; Hovmand, S.R. Prevention of Accidents at Work in Nordic Fisheries: What Has Worked? TemaNord: Copenhagen, Denmark, 23 April 2017. Available online: https://norden.diva-portal.org/smash/ get/diva2:1078287 / FULLTEXT02.pdf (accessed on 1 September 2017).

28. Murray, M.; Fitzpatrick, D.; O'Connell, C. Fishermen's blues: Factors related to accidents and safety among Newfoundland fishermen. Work Stress 1997, 11, 292-297. [CrossRef]

29. Myers, M.L.; Durborow, R.M. Aquacultural Safety and Health. In Health and Environment in Aquaculture; Carvalho, E., Ed.; IntechOpen: London, UK, 2012.

30. Bloswick, B.S.; Husberg, B.J.; Blumhagen, E. Use of Operating Hazard Analysis to Review on-Deck Procedures in Commercial Crab Fishing. In Proceedings of the Second International Fishing Industry Safety and Health Conference, Sitka, AK, USA, 22-24 September 2003; National Institute for Occupational Safety and Health, Centers for Disease Control, USA, DHHS (NIOSH) Publication No. 2006-114, 2003. pp. 45-56. Available online: https://www.cdc.gov/niosh/docs/2006-114/pdfs/2006-114.pdf (accessed on 28 May 2017).

31. Jensen, O.C.; Stage, S.; Noer, P. Classification and coding of commercial fishing injuries by work processes: An experience in the Danish fresh market fishing industry. Am. J. Ind. Med. 2005, 47, 528-537. [CrossRef] [PubMed]

32. Syron, L.N.; Lucas, D.L.; Bovbjerg, V.E.; Bethel, J.W.; Kincl, L.D. Utility of a work process classification system for characterizing non-fatal injuries in the Alaska commercial fishing industry. Int. J. Circumpolar Health 2016, 75, 1-10. [CrossRef] [PubMed]

33. Schulte, P.A.; Rinehart, R.; Okun, A.; Geraci, C.L.; Heidel, D.S. National Prevention through Design (PtD) Initiative. J. Saf. Res. 2008, 39, 115-121. [CrossRef] [PubMed]

34. Wogalter, M.S. Purposes and scope of warnings. In Handbook of Warnings; Wogalter, M.S., Ed.; Lawrence Erlbaum Associates: Mahwah, NJ, USA, 2006; pp. 3-10, ISBN 9780805847246.

35. Haddon, W. Strategies in preventive medicine: Passive vs. active approaches to reducing human wastage. J. Trauma 1974, 14, 353-354. [CrossRef] [PubMed]

36. Jensen, O.C.; Petursdottir, G.; Holmen, I.M.; Abrahamsen, A.; Lincoln, J. A review of fatal accident incidence rate trends in fishing. Int. Marit. Health 2014, 65, 47-52. [CrossRef] [PubMed]

37. Meek, M.; Brown, W.R.; Fulford, K.G. A shipbuilders' view of safety. Marit. Policy Manag. 1985, 12, $251-262$. [CrossRef]

38. Lucas, D.L.; Lincoln, J.M. Fatal falls overboard on commercial fishing vessels in Alaska. Am. J. Ind. Med. 2007, 50, 962-968. [CrossRef] [PubMed] 
39. Backus, A.S.; Brochu, P.J.; Lincoln, J.M.; Bensyl, D.M.; Ciampa, J.R.; Smith, T.J.; Conway, G.A. Work Practices, Entanglement of Lobstermen, and Entanglement Prevention Devices in the Maine Lobster Fishery: A Preliminary Survey. In Proceedings of the International Fishing Industry Safety and Health Conference, Woods Hole, MA, USA, 23-25 October 2000; Lincoln, J.M., Hudson, D.S., Conway, G.A., Pescatore, R., Eds.; Centers for Disease Control and Prevention National Institute for Occupational Safety and Health, 2003; pp. 269-282. Available online: https://www.cdc.gov/niosh/docs/2003-102/pdfs/2003102.pdf (accessed on 28 May 2017).

40. Webster, B.; Birmingham, R.; Jones, E.; Roskilly, T. Developing an Artificially Intelligent Roll Stabilization System for Use on Fishing Vessels. In Proceedings of the 8th International Conference on the Stability of Ships and Ocean Vehicles, Madrid, Spain, 15-19 September 2003; Escuela Tecnica Superior de Ingenieros Navales, 2003; pp. 757-774. Available online: http:/ / www.shipstab.org/files/Proceedings/STAB/STAB2003/Papers/ Paper\%2060.pdf (accessed on 18 June 2017).

41. Bass, D.W. Roll Stabilization for small fishing vessels using paravanes and anti-roll tanks. Mar. Technol. 1998, 35, 74-84.

42. Mirka, G.A.; Ning, X.; Jin, S.; Haddad, O.; Kucera, K.L. Ergonomic intervention for commercial crab fishermen. Int. J. Ind. Ergon. 2011, 41, 481-487. [CrossRef]

43. Fulmer, S. Measuring Risk of Cumulative Musculoskeletal Trauma in Fishing Vessels. In Proceedings of the International Fishing Industry Safety and Health Conference, Woods Hole, MA, USA, 23-25 October 2000; Lincoln, J.M., Hudson, D.S., Conway, G.A., Pescatore, R., Eds.; Centers for Disease Control and Prevention, National Institute for Occupational Safety and Health, 2003; pp. 341-349. Available online: https:/ / www.cdc.gov/niosh/docs/2003-102/pdfs/2003102.pdf (accessed on 28 May 2017).

44. Remmen, L.N.; Herttua, K.; Riss-Jepsen, J.; Berg-Beckhoff, G. Fatigue and workload among Danish fishermen. Int. Marit. Health 2017, 68, 252-259. [CrossRef] [PubMed]

45. Wallace, B. Slip Resistance under Varying Environmental Conditions. In Proceedings of the Second International Fishing Industry Safety and Health Conference, Sitka, AK, USA, 22-24 September 2003; National Institute for Occupational Safety and Health, Centers for Disease Control and Prevention, DHHS (NIOSH) Publication No. 2006-114. 2003; pp. 45-56, 65-75. Available online: https: / www.cdc.gov/niosh/ docs/2006-114/pdfs/2006-114.pdf (accessed on 28 May 2017).

46. Durborow, R.M.; Myers, M.L.; Kane, A.S. Clam Mariculture Safety in South Carolina: A Case Study. In Proceedings of the Fifth International Fishing Industry Safety and Health Conference, St. John's, NL, Canada, 10-13 June 2018.

47. Turner, S.; Wylde, J.; Langham, M.; Sharpe, S.; Jackson, K. MCA Lifejacket Wear-Behavioral Change. 12 August 2009. Maritime Coastguard Agency \& the Royal National Lifeboat Institution, United Kingdom. Available online: http:/ / www.nasbla.org/HigherLogic/System/DownloadDocumentFile.ashx? DocumentFileKey=67784c66-3c9e-4003-8c31-f5258cc9e4f6\&forceDialog=0 (accessed on 1 June 2017).

48. Lucas, D.; Lincoln, J.; Somervell, P.; Teske, T. Worker satisfaction with personal flotation devices (PFDs) in the fishing industry: Evaluations in actual use. Appl. Ergon. 2012, 43, 747-752. [CrossRef] [PubMed]

49. Brooks, C.J.; Howard, K.A.; Neifer, S.K. How much did cold shock and swimming failure contribute to drowning deaths in the fishing industry in British Columbia 1976-2002? Occup. Med (Lond). 2005, 55, 459-462. [CrossRef] [PubMed]

50. Lucas, D.L.; Lincoln, J.M.; Carozza, S.E.; Bovbjerg, V.E.; Kincl, L.D.; Teske, T.D.; Somervell, P.D.; Anderson, P.J. Predictors of personal flotation device (PFD) use among workers in the Alaska commercial fishing industry. Saf. Sci. 2013, 53, 177-185. [CrossRef]

51. Lucas, D.L.; Lincoln, J.M.; Teske, T. Intervention Development (Part 1): Personal Flotation Device Use among Commercial Fishermen: Evaluations of Comfort. In Proceedings of the Council of State and Territorial Epidemiologists Annual Conference, Anchorage, AK, USA, 19-23 June 2016. Available online: https: / / cste.confex.com/cste/2016/webprogram/Paper6644.html (accessed on 1 June 2017).

52. National Institute for Occupational Safety and Health. DHHS (NIOSH) Publication Number 2013-131. Centers for Disease Control and Prevention, US Department of Human Services. Available online: https: / / www.cdc.gov/niosh/docs/2013-131/default.html (accessed on 19 April 2018).

53. Sorensen, J. The Use of Personal Flotation Devices in the Northeast Lobster Fishing Industry: An Examination of the Decision Making Process. In Proceedings of the 19th Triennial Congress of the International Ergonomics Association, Melbourne, Australia, 9-14 August 2015. 
54. Weil, R. Lobstermen test new PFD designs. Natl. Fisherman 2017, 98, 6-7.

55. Rosenthal, F.S.; Phoon, C.; Bakalian, A.E.; Taylor, H.R. The ocular dose of ultraviolet radiation to outdoor workers. Invest. Ophthalmol. Vis. Sci. 1988, 29, 649-656. [PubMed]

56. Dzugan, J. 25 Years of Training Commercial Fishermen. In Proceedings of the National Transportation Safety Board Fishing Vessel Safety Forum, Washington, DC, USA, 13-14 October 2010. Available online: https:/ /www. ntsb.gov/news/events/Documents/2010_Fishing_Vessel_Safety_FRM-Panel6b3-Dzugan.pdf (accessed on 4 September 2017).

57. Pfeiffer, L.; Gratz, T. The effect of rights-based fisheries management on risk taking and fishing safety. Proc. Natl. Acad. Sci. USA 2016, 113, 2615-2620. [CrossRef] [PubMed]

58. Marvasti, A.; Dakhlia, S. Occupational safety and the shift from common to individual fishing quotas in the Gulf of Mexico. South Econ. J. 2017, 83, 705-720. [CrossRef]

59. Törner, M.; Cagner, M.; Nilsson, B.; Nording, P.-O. Occupational injury in Swedish fishery: 2. Promoting implementation of safety measures. Occup. Ergon. 1999/2000, 2, 91-104.

60. Hall-Arber, M.; Mrakovcich, K.L. Reducing risk to life and limb: Safety training steps towards resilience in Massachusetts' commercial fishing industry. Hum. Ecol. Rev. 2008, 15, 201-212.

61. Dzugan, J. The development and efficacy of safety training for commercial fishermen. J. Agromed. 2014, 19, 351-356. [CrossRef] [PubMed]

62. Craig, B. Commercial Fishing Vessel Safety and the National Marine Fisheries Service-United States Coast Guard Memorandum on Observer Safety. Report to the National Observer Program National Marine Fisheries Service Office of Science and Technology; December 2014. Available online: https:/ /www.st.nmfs. noaa.gov/Assets/Observer-rogram/pdf/MoA_\&_Safety_Decal_Report_v5_Final_rev-1.pdf (accessed on 27 May 2017).

63. Murray, M. The Use of Narrative Theory in Understanding and Preventing Accidents in the Fishing Industry. In Proceedings of the International Fishing Industry Safety and Health Conference, Woods Hole, MA, USA, 23-25 October 2000; Lincoln, J.M., Hudson, D.S., Conway, G.A., Pescatore, R., Eds.; Centers for Disease Control and Prevention, National Institute for Occupational Safety and Health, 2000; pp. 243-250. Available online: https: / / www.cdc.gov/niosh/docs/2003-102/pdfs/2003102.pdf (accessed on 7 June 2017).

64. Howe, B.L. Stability Training for Fishermen: Anchored Instruction Using Narrative Theory and Video for Learning Transfer. In Proceedings of the Second International Fishing Industry Safety and Health Conference, Sitka, AK, USA, 22-24 September 2003; National Institute for Occupational Safety and Health, Centers for Disease Control and Prevention, DHHS (NIOSH) Publication No. 2006-114, 2003. pp. 263-280. Available online: https: / / www.cdc.gov/niosh/docs/2006-114/pdfs/2006-114.pdf (accessed on 28 May 2017).

65. Teutsch, S.M. A framework for assessing the effectiveness of disease and injury prevention. MMWR 1992, 41, 1-12. [PubMed]

66. Sienkiewicz, J.M. Forecasting Extreme Ocean Waves. In Proceedings of the International Fishing Industry Safety and Health Conference, Woods Hole, MA, USA, 23-25 October 2000; Lincoln, J.M., Hudson, D.S., Conway, G.A., Pescatore, R., Eds.; Centers for Disease Control and Prevention, National Institute for Occupational Safety and Health, 2003; pp. 123-130. Available online: https://www.cdc.gov/niosh/docs/ 2003-102/pdfs / 2003102.pdf (accessed on 28 May 2017).

67. Wu, Y.; Pelot, R.P.; Hilliard, C. The effect of weather factors on the severity of fishing boat accidents in Atlantic Canada. Risk Manag. 2005, 7, 21-40. [CrossRef]

68. Wu, Y.; Pelot, R.P.; Hilliard, C. The influence of weather conditions on the relative incident rate of fishing vessels. Risk Anal. 2009, 29, 985-999. [CrossRef] [PubMed]

69. Woodley, C. Quota-Based Fishery Management Regimes. In Proceedings of the International Fishing Industry Safety and Health Conference, Woods Hole, MA, USA, 23-25 October 2000; Lincoln, J.M., Hudson, D.S., Conway, G.A., Pescatore, R., Eds.; Centers for Disease Control and Prevention, National Institute for Occupational Safety and Health, 2003; pp. 161-171. Available online: https:/ /www.cdc.gov/niosh/docs / 2003-102/pdfs / 2003102.pdf (accessed on 28 May 2017).

70. Jepsen, J.R.; Zhao, Z.; Pekan, C.; Barnett, M.; van Leeuwen, W.M.A. Risk factors for fatigue in shipping, the consequences for seafarers' health and options for preventive action. In Maritime Psychology: Research in Organizational\& Health Behavior at Sea; MacLachlan, M., Ed.; Springer: Cham, Switzerland, 2017; pp. 127-150, ISBN 978-3-319-45428-3. [CrossRef] 
71. Runyan, C.W. Introduction: Back to the future-Revisited Haddon's conceptualization of injury epidemiology and prevention. Epidemiol. Rev. 2003, 25, 60-64. [CrossRef] [PubMed]

72. Barnett, D.J.; Balicer, R.D.; Blodgett, D.; Fews, A.L.; Parker, C.L.; Links, J.M. The application of the Haddon matrix to public health readiness and response planning. Environ. Health Perspect. 2005, 113, 561-566. [PubMed]

73. Quan, L.; Osborne, J. 2011-2016 Washington State Open Water Drowning Prevention Policy Plan for Children and Youth; Final Grant Report, Executive Summary; Seattle Children's Hospital, University of Washington School of Medicine and Naval Base Kitsap: Seattle, WA, USA, 2016.

74. Myers, M.L. Occupational Safety and Health Policy; American Public Health Association: Washington, DC, USA, 2015; pp. 24-25, ISBN 978-0-87533-271-4.

75. Hornbeak, K.B.; Auerbach, P.S. Marine envenomation. Emerg. Med. Clin. N. Am. 2017, 35, 321-337. [CrossRef] [PubMed]

76. Martinis, V.A. The Noise Profile and Hearing Levels of Commercial Fishermen. Master's Thesis, University of Washington, Seattle, WA, USA, 1977.

77. Thalmann, E.D. Diving hazards. In Safety and Health in Agriculture, Forestry, and Fisheries; Langley, R.L., McLymore, R.L., Meggs, W.J., Roberson, G.T., Eds.; Government Institutes: Rockville, MD, USA, 1997; pp. 617-641, ISBN 13 978-0865875524.

78. Fishing Partnership Support Services Burlington, MA, USA. Available online: http:/ / fishingpartnership. org/services / (accessed on 10 September 2017).

(C) 2018 by the authors. Licensee MDPI, Basel, Switzerland. This article is an open access article distributed under the terms and conditions of the Creative Commons Attribution (CC BY) license (http:/ / creativecommons.org/licenses/by/4.0/). 